\title{
Harnessing the Export Opportunities in Pomegranate to Enhance the Income of the Growers
}

\author{
B.N. Anaida, K.P. Raghuprasad, Tanweer Ahmed* and B.N. Mrunalini \\ Department of Agricultural Extension, GKVK, UAS, Bangalore, India \\ *Corresponding author
}

\begin{abstract}
A B S T R A C T
Pomegranate is a high value crop having great economic importance. Apart from its demand for fresh fruits and juice, the processed products like wine and candy are also gaining importance in world trade. Demand in the international market has widened the scope for earning higher dividends from this crop. Consequently production is expected to increase by ten folds in recent years. Bagalkot is one of the major pomegranate growing districts of Karnataka where the variety Bhagwa is cultivated extensively which is well suitable for export purpose. In order to get more export opportunities in pomegranate, farmers need to have required knowledge about export quality parameters. Hence a study was conducted to analyse the knowledge level of pomegranate growers about quality parameters of pomegranate for export. Ex post facto research design was used for the study. Data was collected using structured interview schedule Results showed that among different pomegranate export parameters, $86.67 \%$ of the respondents were aware about fruit weight, fruit size $(85.00 \%)$, fruit shape $(81.67 \%)$ and fruit colour $(80.00 \%)$. Further results revealed that $61.67 \%$ of respondents were not aware of mealy bug infestation, 53.33 per cent of them did not have knowledge about thrips damage, 50.00 per cent had no knowledge of chemical residue and $(46.67 \%)$ were unaware of fruit flavour. The above results clearly indicate that majority of the farmers know about important physical parameters like fruit shape, fruit size, fruit colour and not aware about other parameters which determining export value. Regarding over all knowledge of pomegranate growers about export quality parameters, 38.33 per cent of them having medium knowledge followed by high knowledge $(36.67 \%)$ and low knowledge $(25 \%)$ respectively. Hence there is a need to create awareness among pomegranate growers regarding these aspects so that the farmers know about export quality parameters which enable them to export more quantity so that they can harness available export opportunity and these by increase their income level.
\end{abstract}

\section{Keywords}

Knowledge, Pomegranate, Export parameters

Article Info

Accepted:

12 October 2018 Available Online:

10 November 2018

\section{Introduction}

Pomegranate is a rich source of sodium and also contains a good amount of riboflavin, thiamin, niacin, vitamin $\mathrm{C}$, calcium and phosphorous. All parts of pomegranate tree have great therapeutic value and are used in leather and dying industry. Demand in the international market has widened the scope for earning higher dividends from this crop. Profits up to 1.5 lakhs/ha/annum have been realized by some growers. There has been a 
steady increase in area and production of pomegranate in the country. It is estimated that by the year 2025, the area under pomegranate is projected to increase to 7.5 lakhs ha, from 1.25 lakhs ha at present.

Consequently production is expected to increase by 10 folds. The variety Bhagwa (Red Ruby) cultivated in Bagalkot is suitable for export purpose. A set of export quality parameters laid out for export of pomegranate in order to exploit more export opportunities in pomegranate farmers need to have required knowledge about export quality parameter. Hence a study was carried out to assess the knowledge of pomegranate growers with respect to export quality parameters

\section{Materials and methods}

The present study was conducted in Bagalkot district of Karnataka state during the year 2017-18. Ex Post facto research design was used for the study. Two taluks viz., Kaladgi and Govindakoppa were covered. From each taluk, 30 farmers were randomly selected making a total sample size of 60. Data were collected using a pretested structured interview schedule. Data were analyzed using appropriate statistical tools like Frequency, Mean, Percentage, Standard Deviation etc.

\section{Knowledge level}

Knowledge is operationalised as the factual information possessed by pomegranate growers regarding export parameters. Teacher made test suggested by Anastasi, A, (1961) and followed by Tanweer Ahmed (2015) was employed to measure the knowledge level of respondents. Data was collected from structure interview schedule through personal interview method.The answers elicited from the respondent were quantified by giving score of one for correct answer and zero to incorrect answer.

\section{Results and Discussion}

\section{Component wise knowledge level of Pomegranate growers}

Table 1 depicts the component wise knowledge level of pomegranate growers with respect to export quality parameters, It is observed that about 86.67 per cent of the pomegranate growers have knowledge about fruit weight and 85 percent of the growers know about the fruit size due to the reason that, consumers prefer bigger size fruits depends upon the size of the fruits and it can also facilitates easy transportation for distant places. 81.67 per cent know about fruit shape and 80 per cent know about the fruit colour since fruit shape and colour also determine the value due to consumer's preference and attraction towards the fruits.

In other hand 61.67 percent of the pomegranate growers don't have proper knowledge about mealy bag damage, 53.33 per cent don't know about thrips damage, and 50 percent of the growers don't have knowledge about chemical residue and 46.67 per cent don't know about fruit flavour since the fruit has lot of medicinal value, the growers could also add to the market value to fruit flavour because these two will negatively influences the price and lesser consumer preference knowledge about chemical residue normally for export agencies are very strict with regard to chemical residue and even rejected the lot due to these reason.

\section{Overall knowledge level of pomegranate growers}

The results presented in Table 2 shows that 38.33 per cent of the respondents were found to possess medium level of overall knowledge regarding export quality parameters followed by high $(36.67 \%)$ and $\operatorname{low}(25 \%)$ with a mean score of 28.71 (Fig. 1). 
Data were analyzed using appropriate statistical tools like frequency, mean, percentage, standard deviation etc.

\begin{tabular}{|l|c|}
\hline \multicolumn{1}{|c|}{ Category } & Criteria \\
\hline Low & $<($ Mean $-1 / 2 \mathrm{SD})$ \\
\hline Medium & $($ Mean $\pm 1 / 2 \mathrm{SD})$ \\
\hline High & $>($ Mean $+1 / 2 \mathrm{SD})$ \\
\hline
\end{tabular}

Table.1 Knowledge level of pomegranate about export parameters

\begin{tabular}{|r|l|c|c|c|c|}
\hline S. No. & \multicolumn{1}{|c|}{ Particulars } & A ware & Percentage & Not A ware & Percentage \\
\hline 1. & Fruit weight & 52 & 86.67 & 08 & 13.33 \\
\hline 2. & Fruit Size & 51 & 85.00 & 09 & 15.00 \\
\hline 3. & Fruit Shape & 49 & 81.67 & 11 & 18.33 \\
\hline 4. & Fruit Colour & 48 & 80.00 & 12 & 20.00 \\
\hline 5. & Sugar content & 40 & 66.67 & 20 & 33.33 \\
\hline 6. & Bacterial spots & 38 & 63.33 & 22 & 36.67 \\
\hline 7. & Sunburn marks & 35 & 58.33 & 15 & 25.00 \\
\hline 8. & Chemical residues & 30 & 50.00 & 30 & 50.00 \\
\hline 9. & Fruit flavor & 32 & 53.34 & 28 & 46.67 \\
\hline 10. & Thrips damage fruits & 28 & 46.67 & 32 & 53.33 \\
\hline 11. & Mealy bug damage & 23 & 38.33 & 37 & 61.67 \\
\hline
\end{tabular}

Table.2 Overall knowledge level of pomegranate about export quality parameters

\begin{tabular}{|c|c|c|c|c|}
\hline \multirow{2}{*}{$\begin{array}{l}\text { Sl. } \\
\text { No. }\end{array}$} & \multirow[t]{2}{*}{ Knowledge } & \multirow[t]{2}{*}{ Criteria } & \multicolumn{2}{|c|}{ Knowledge } \\
\hline & & & Frequency & Per cent \\
\hline 1. & Low & $<25.78$ & 15 & 25.00 \\
\hline 2. & Medium & 25.78 to 31.66 & 23 & 38.33 \\
\hline 3. & High & $>31.66$ & 22 & 36.67 \\
\hline Mean & 8.71667 & $\mathrm{SD}=5.87754$ & & \\
\hline
\end{tabular}


Fig.1 Overall knowledge level of the pomegranate growers

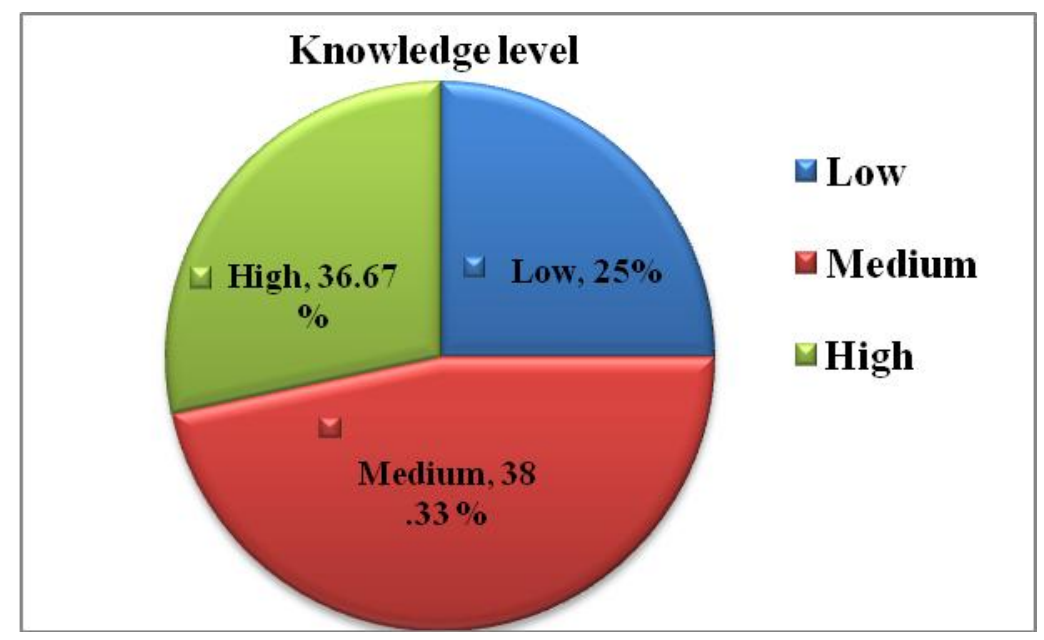

Pomegranate being high value crop growing to get more returns normally requires knowledge for its marketing and export quality parameters. Hence majority of them fall under medium to high category and less percent belong to low knowledge category. 25 per cent of respondent possess low knowledge regarding export quality parameters. The reason for this may be due to their traditional way of farming and more dependence on local market and reluctance to take risk of export. Further they clearly know that unless they possess knowledge their product were not fit for export and they may reject at any point of time. Further possessing knowledge by themselves helps to avoid exploitation of middle man and increase the return.

From the above results it can be concluded that since 38.33 per cent of the growers belonged to medium category and 25.00 per cent of them belong to low category of overall knowledge level there is a need to organize intensive educational activities such as trainings, exhibitions, field days, field visits etc. effectively and frequently and follow up of these activities by the concerned agencies for achieving higher levels of knowledge in pomegranate growers. The above finding shows that majority of the farmers aware about physical characters like fruit size, shape, colour and not aware about chemical residue, thrips, mealy bug infestation which leads to less export of the commodity. Pomegranate growers belong to medium to low category of knowledge. These results throw light and demands extension professions to evolve appropriate strategies so that knowledge level of pomegranate can be increased which in turn promotes export of pomegranate and enhance the economic status of the growers

\section{References}

Anastasi, A., (1961). Psychological testing. Mac Millan Publishing Co., Inc. New York. P. 428- 436

Atchuta Raju, K. and Radha Krishnamurthy, 2002, Knowledge level of betel vine growers, Journal of Extension Education, 13 (1): 3271-3276.

Koujalagi, C. B., Patil, B.L. and Murthy, C., 2014, Growth trends in area, production, productivity and export of pomegranate in Karnataka: An economic analysis. Internat. J. Com., 7 (1): 11-15.

Nagesh, 2006, Study on entrepreneurial behaviour of pomegranate growers in Bagalkot district of Karnataka, M.Sc. 
(Agri.) Thesis (Unpub), Univ. Agric. Sci., Dharwad

Negi, Y.S., R.S. Prasher and S.C. Tiwari, 1994, Analysis of India's Horticultural Exports Status and Export Strategies. Indian Journal of Agricultural Marketing. 8 (3): 25-29.

Raghuprasad, K.P., Pasha, M. and Tanweer, Ahmed, 2018, Relationship between adoption pattern and socio economic profile of pomegranate growers. International journal of agriculture sciences, 10 (5): 5251-5254
Siddappa, C. Angadi, 1999, Study on knowledge, adoption and marketing pattern of pomegranate growers in Bagalkot district. M. Sc. (Agri.) Thesis (Unpub.), Univ. of Agric. Sci., Bangalore.

Tanweer Ahmed, Shwetha N.V., Narayana Swamy B.K. and Murtuza Khan, 2016, Knowledge level of farm facilitators under Bhoochetana programme of KSDA in Chickballapur district of Karnataka. Progressive Research - An International Journal. 11 (4): 34383440

\section{How to cite this article:}

Anaida, B.N., K.P. Raghuprasad, Tanweer Ahmed and Mrunalini, B.N. 2018. Harnessing the Export Opportunities in Pomegranate to Enhance the Income of the Growers. Int.J.Curr.Microbiol.App.Sci. 7(11): 1594-1598. doi: https://doi.org/10.20546/ijcmas.2018.711.181 